\title{
Association Between Self-Efficacy and Aggression Among College Students
}

\author{
Patil Vishwanath Malagonda', Vikas S. Minchekar² \\ 1Department of Psychology, Dr. Ghali College, Gadhinglaj, India \\ 2Department of Psychology, Shivaji University, Kolhapur, India \\ Corresponding E-mail: vikasminchekar@yahoo.com
}

\begin{abstract}
Aggressive behavior in sports and group performance is critical in today's scenario. Self-efficacy can play a crucial role in aggressive behavior. Hence, to test this assumption study was undertaken to assess the association between self-efficacy and aggression. It was hypothesized that self-efficacy and aggression are positively and significantly related to each other. This study's sample contained 80 students, and they were recruited from Dr. Ghali College, Gadhinglaj. The sampling technique was non probability sampling in which everyone doesn't have the same chance for being chosen as a sampling. This study administered self-efficacy measure using the scale by G. P. Mathur and Dr. Raj Kumari Bhatnagar and aggression scale by G. P. Mathur and Dr. Raj Kumari Bhatnagar to 40 male and 40 female college students. Obtained data were analyzed by Student t-test and PPMCC test. Results revealed that there is a significant sex difference in self-efficacy and aggression. Moreover, the association between self-efficacy and aggression among college students was also found significant.
\end{abstract}

Keywords: Self Efficacy, Aggression, College Students

\begin{abstract}
Abstrak
Perilaku agresif dalam olahraga dan kinerja kelompok sangat penting dalam skenario saat ini. Efikasi diri dapat memainkan peran penting dalam perilaku agresif. Oleh karena itu, untuk menguji asumsi ini dilakukan studi untuk menilai hubungan antara efikasi diri dan agresi. Diduga bahwa self-efficacy dan agresi berhubungan secara positif dan signifikan satu sama lain. Sampel penelitian ini terdiri dari 80 siswa, dan sampel berasal dari Dr. Ghali College, Gadhinglaj. Teknik pengambilan sampel adalah non-probability sampling di mana setiap orang tidak memiliki kesempatan yang sama untuk dipilih sebagai pengambilan sampel. Penelitian ini menggunakan pengukuran efikasi diri menggunakan skala G. P. Mathur dan Dr. Raj Kumari Bhatnagar serta skala agresi oleh G. P. Mathur dan Dr. Raj Kumari Bhatnagar kepada 40 mahasiswa pria dan 40 wanita. Data yang diperoleh dianalisis dengan uji $t$ Student dan uji PPMCC. Hasil penelitian menunjukkan bahwa ada perbedaan jenis kelamin yang signifikan dalam efikasi diri dan agresi. Selain itu, hubungan antara efikasi diri dan agresi di kalangan mahasiswa juga ditemukan signifikan.
\end{abstract}

Kata Kunci: Efikasi diri, Agresi, Mahasiswa 


\section{Introduction}

Children do not only thrive to obtain achievements in school but also to get along with others for their positive quality development that may be useful in the following years of maturation. Several studies attempt to identify the main factors influencing children's development. Studies found a relationship between belief of one's capability to perform certain task (self-efficacy) and the execution of said task (e.g., Bandura, 1986). Self-efficacy is the belief that ensures us about our ability which carries out actions that produce desirable outcomes. According to Thompson (2009), the people with high self-efficacy will have more confidence when interacting with external stimuli such as threat or environmental stimulus. High self-efficacy will help an individual to interact with others successfully, understand acquired information, and deal with adversities then come out with a solution, while low self-efficacy will hinder one's ability to adapt. Self-efficacy is the perception of our abilities that controls potential stressors from surrounding us that may affect us.

The research conducted by Bandura and Locke (2003) found that the people who have high selfefficacy show higher aspiration and more remarkable work persistence to attain goals than those with lower self-efficacy. Aggression has many definitions in nature as it can be defined as any physical or verbal behavior intended to hurt or destroy others. Bushman and Anderson (2002) found that their general aggression model (GAM) includes three variables that may lead to overt aggression: (1) arousal that may influence physiological response of arousal; (2) affective states may be a catalyst for feelings of hostility and its expression such as channeling anger through body language; (3) cognitions may affect someone's mental state and shift it into negative or aggressive thoughts.

The relationship between belief and behaviour theorizes belief as predictor of an individual behaviour across developmental ages. According to many social science studies, several stages of age or belief systems may not be relevant to this theory.

A study conducted by Hastuti (2018) defined aggression as inherited primitive behaviour as a mean of survival through the ages, but nowadays, aggression has various motivations besides only to survive. Aggressive behaviour usually involves behaviours such as physically or verbally harming others, vandalism, or any other forms of destructive behaviour (DeWall, Finkel, \& Denson, 2011). These destructive behaviours may create social problems as it is most often not aligned with the values or norms in society.

Social psychological theory categorizes aggression into two components: (1) physical aggression, in which aggressive individual will pose a threat to others through harmful physical contacts such as hitting, smashing, kicking, or slapping. The physical contacts may be influenced by impulse or deliberate intention and it may cause light or severe damage to the targeted person or belonging; (2) non-physical aggression, which refers to the non-physical form of aggressive contacts such as through verbal (yelling, mocking, insulting, shaming) or through social/relational aggression (gossiping, social isolation, and teasing others with racial or offensive slurs). Through the development of modern ages, social media may also influence the rate of which aggressive behaviour may increase as social media becomes easier to access.

Other studies also categorized aggression into two subtypes: (1) impulsive aggression that refers to the state that easily triggered hostility or aggression towards provocative stimulus with lack of control; (2) premeditated aggression which refers to a deliberate aggression, non-spontaneous, and it is done consciously.

Aggression has many dimensions depending on the theory used to explain aggression per se, one of the most widely known dimensions to help researcher explain aggression is the dimension from the Buss-Perry Aggression Questionnaire developed by Buss \& Perry (Gallagher \& Ashford, 2016). 
The questionnaire which comprises 29 items measures aggression through four dimensions, namely physical aggression, verbal aggression, anger, and hostility. While physical and verbal aggression may be self-explanatory, anger and hostility may seem similar in its characteristics. Anger refers to physiological reactions that reflect an individual's emotional elements, while hostility implies the existence of conflicting feelings of injustice which refers to cognitive elements. In the past study, the levels of physical aggression and anger differ in genders. Males have higher level of both physical aggression and anger compared to females (Reyna, Sanchez, Ivacevich, \& Brussino, 2011).

Another relevant discussion on aggression is the relationship between self-control and aggressive behaviour. DeWall et al (2011) believed that self-control can predict aggressive behaviours in individuals as without excellent self-control, individuals may not be able to suppress the aggression or any criminal and violent behaviours. Self-control refers to an individual's ability to adapt their behaviour so that it fits the social norms and values in society. Self-control also implies the willingness to adapt to the standard of others or society by setting aside impulsive behaviour and spontaneous responses which stem from habits (Tangney, Baumeister, \& Boone, 2004; Baumeister, Vohs, \& Tice, 2007).

Every person has different degree of self-control. Some people may have better self-control as a result of persistent training they underwent to achieve higher level of self-control in order to obtain better and balanced life. While others may have difficulties in controlling their impulses, anger, or any type of harmful desires. With the diverse level of self-control, the externalization of aggression may also differ across people since the expression of aggressive behaviour may be controlled by selfcontrol even when that individual has high tendency of aggression. Self-control may act as weakening factor to aggression, meaning that the higher self-control is, the lower aggression is, and vice versa (DeWall et al, 2011). Several other studies also found negative correlation between self-control and aggression which further prove this theory.

A thesis conducted by Hartono (2012) defined self-efficacy as an individual's belief of their ability to complete their works or assigned tasks in order to reach certain goals. People with high selfefficacy are capable of transforming adversities into challenges and coming out of the difficult situation as better individuals with higher skills or abilities. Self-efficacy implies how confident someone is when it comes to reach success.

According to Bandura (1994), self-efficacy is a self-evaluation process in which an individual creates personal judgment towards one's own abilities and skills. Self-efficacy also influences cognitive process, including decision-making, problem-solving, rationalization, and personal achievements. Self-efficacy is also reflected through a person's behaviour in their effort to maintain motivation, face challenges, adapt to new environment, keep being persistent, explore various environments, and solve problems.

People with high self-efficacy will percept the given tasks as challenges in which their abilities and skills will be put to test. They perceive failure as a way to learn from mistakes and coming out stronger and better than before. While people with low self-efficacy will tend to perceive difficult tasks as adversities or threats, therefore the fear of failure and the willingness to eliminate or remove the tasks are dominant in people with lower self-efficacy. This situation will eventually cause stress or even depression (Pajares \& Schunk, 2001).

In general, self-efficacy is defined as the individual's belief of their own ability and capability in which self-assessment is important to find whether they may or may not be able to complete given tasks using possessed abilities and skills. In conclusion, it refers to self-judgment of someone's competency and abilities (Wei et al., 2008). Based on the definition, it is clear that having high self- 
efficacy may help an individual to better regulate their emotions, physical conditions, and regulate external expression of aggressive behaviour.

Factors that may influence an individual's level of self-efficacy are the mastery of experience, modelling, social persuasion, and stress relief. First, mastery of experience refers to the acquisition of self-efficacy through learning from experience of achieving success. To achieve bigger things, an individual must be willing to sacrifice many resources (e.g. time and energy). Through the courage to face challenges, an individual will in turn create confidence in his own abilities and skills. Through this success, an individual's self-efficacy will increase while failure will destroy the individual's selfefficacy specifically if the self-efficacy hasn't been built before the said failure took place (Bandura, 1994).

Second, modelling process through observation of others may cause an individual to feel as if they have experienced the success of others as a part of their own personal experience. When experiencing failure, someone may refer to others in search of hope and guidance, thus resulting in an increase of self-efficacy after modelling someone else's success and their processes or efforts to achieve the success. Meanwhile, only observing and witnessing someone's failure may affect an individual's selfefficacy negatively as they may believe if somebody else can't do it, so can't they (Bandura, 1994).

Third, an individual can strengthen self-efficacy through social persuasion from others (Logsdon et al, 2010). For example, verbal and non-verbal evaluation from others, in which positive social persuasion includes compliment, appreciation, and other positive evaluation, while negative social persuasion includes underestimation, insults toward one's ability, and other negative evaluations. Positive social persuasion increases someone's self-efficacy and vice versa.

Fourth, stress relief may affect an individual's self-efficacy as stress is a collection of negative emotions as a result of the discrepancy between one's resources and the existing demands. People who can relief their stress will have more passion to work and live their life if compared to those who have high stress level. With less stress, someone will have less self-doubt about their abilities, skills, or capabilities as they have less worry about not being able to complete their tasks or reach their goals (Bandura 1994).

Bandura (1973) stated in his social cognitive theory the cognitive bias of the aggressor and low self-efficacy may predict aggressive behaviour (Ganooverway et al., 2009). Strong self-efficacy may be able to control someone's aggressive tendency efficacy (Bandura, 1994; Bandura, 1997). Several researchers found that self-efficacy in a person's emotion regulation may help in regulating the desire to express aggression externally and other types of criminal behaviour (Caprara et al., 2010; e.g., Wu et al., 2015). Furthermore, self-efficacy is a good predictor of aggressive behaviour in which both are negatively related, meaning the higher one's self-efficacy, the lower one's tendency of aggression (e.g., Buser et al., 2015).

A study by Michele Willems (2008) about the relationship between self-efficacy and aggression using a sample of 344 adolescents with various socioeconomic background found a significant negative correlation between self-efficacy and aggression. This study also found different level of aggression in both genders, meaning that male and female samples may have significantly different scores in aggression.

A study by Tuncay and Murat (2020) titled "Examining the relationship between self-efficacy and aggression levels of students interested in weightlifting sports" on 337 athletes found that there is a negative significant low correlation between self-efficacy and aggressive behaviour among participants. 
Despite many researches found significant negative correlation between self-efficacy and aggression, a study by Hadley et al (2015) found significant positive correlation between self-efficacy and aggression. Furthermore, this study hypothesize that self-efficacy mediates the approval of aggression and proactive aggression in both males and females. Bandura (1997) believed that a person acts based on the belief they currently possess, if they believe of their capability they will act upon that belief and behave accordingly. The same applies for aggressive behaviour, if an individual believe they are capable of executing aggressive behaviours they will externalize the tendency into actions.

The result of a study by Hadley et al (2015) found that males score higher in proactive aggression, approval aggression, and self-efficacy compared to their counterparts supporting the theory that males are more aggressive than females in general. This may be a result of male's representation in society. The result also shows significant mediating relationship between approval of aggression and proactive aggression in which self-efficacy acts as mediator.

Perry et al (1986) stated that people with high aggression believe that being aggressive is a normal and justified action in which they are confident the act will reward them with positive outcome. This justification rarely comes with rational thoughts or cognitive processes.

One of the most popular theory to explain the belief is social dominance theory where the individual believes that aggression can be the symbol of dominance in society. As aggression usually inflicts fear to the target of aggressive behaviour, people with dominating tendency will try to assert their dominance through it. This also indicates that self-efficacy may influence a person's approval of aggressive behaviour in social environment.

In the young adult developmental stages, such as in the period of college or universities, students spare much of their time on building networks and meaningful interpersonal relationship in which conflicts or miscommunications may arise. If the students have high self-efficacy or beliefs on their ability of carrying out aggression, they might have difficulties on forming long-lasting bond of friendship or intimate relationship with others as they have higher tendency of aggression towards their friends or partners.

Despite diverse results across studies on the relationship between self-efficacy and aggression, this study hypothesizes self-efficacy and aggression to have significant positive correlation. Differing results across many studies on the similar variables may be the consequence of different theory used in each studies and different instrument with different measuring dimensions.

\section{Objectives}

1. To find out the relationship between self-efficacy and aggression among college-going male students.

2. To find the association between self-efficacy and aggression among college-going female students.

\section{Hypotheses}

1. There will be a positive correlation between self-efficacy and aggression among female college students.

2. There will be a positive correlation between self-efficacy and aggression among male college students. 


\section{Method}

\section{Sample}

To study the relationship between aggression and self-efficacy, $\mathbf{8 0}$ college students were randomly selected from Dr. Ghali College, Gadhinglaj. The age range of these students was 18 to 21 years. The reason of choosing sampling is according to developmental stage theory, people at this stage tends to seek out of intimacy with other people through friendship. Sometimes this process doesn't run smoothly and people become aggression towards other, therefore, the objective of this research is to see the relation between self-efficacy with aggression. Hopefully, students who has high self-efficacy will have more control on their behavior.

\section{Instruments}

The following Standardized tests are used to collect data.

\section{Aggression Scale}

There are so many scales that can be used to measure aggression behavior. The scale that has been used in this research was developed by Dr. G. P. Mathur and Dr. Raj Kumari Bhatnagar. This test is in Hindi and English versions consists of 55 statements having positive and negative forms. There are five alternatives for each item. The reliability test shows a coefficient of .88 for males, and .81 for females, and validity coefficient of .80 for males and .78 for females. 2012. This scale was more compatible and represent the students in India because it was developed with India's sample as well.

\section{Self-Efficacy Scale}

The scale was prepared by Dr. G. P. Mathur and Raj Kumari Bhatnagar in Hindi and English language. It can be assessed to measure the self-efficacy of the above 14 years age group. The test consists of 22 positive and negative items. The reliability coefficient of the scale is .7. Another scale that also could be used for measuring self - efficacy in self efficacy scale by U Scholtz, et al (2002) which consists less item compared with the previous one, however, the scale that has been used in this research can represent India's people better.

\section{Statistical Analysis}

The data were statistically analyzed by the Mean, SD, and correlation coefficient and t value to find out a relationship between self-efficacy and aggression.

\section{Results}

Table 1

Mean, SD, and t-test values of aggression and self-efficacy of male and female students.

\begin{tabular}{c|c|c|r|c|c|c|c} 
& Sex & N & Mean & $\begin{array}{c}\text { Std. } \\
\text { Deviation }\end{array}$ & Df & T & Significance \\
\hline \multirow{2}{*}{ Aggression } & Female & 40 & 188.2500 & 11.05406 & 78 & 10.38 & 0.01 \\
\cline { 2 - 6 } & Male & 40 & 215.3500 & 12.26325 & 78 & \multirow{2}{*}{0.01} \\
\hline $\begin{array}{c}\text { Self- } \\
\text { Efficacy }\end{array}$ & Female & 40 & 62.4500 & 1.88040 & 78 & 11.88 &
\end{tabular}



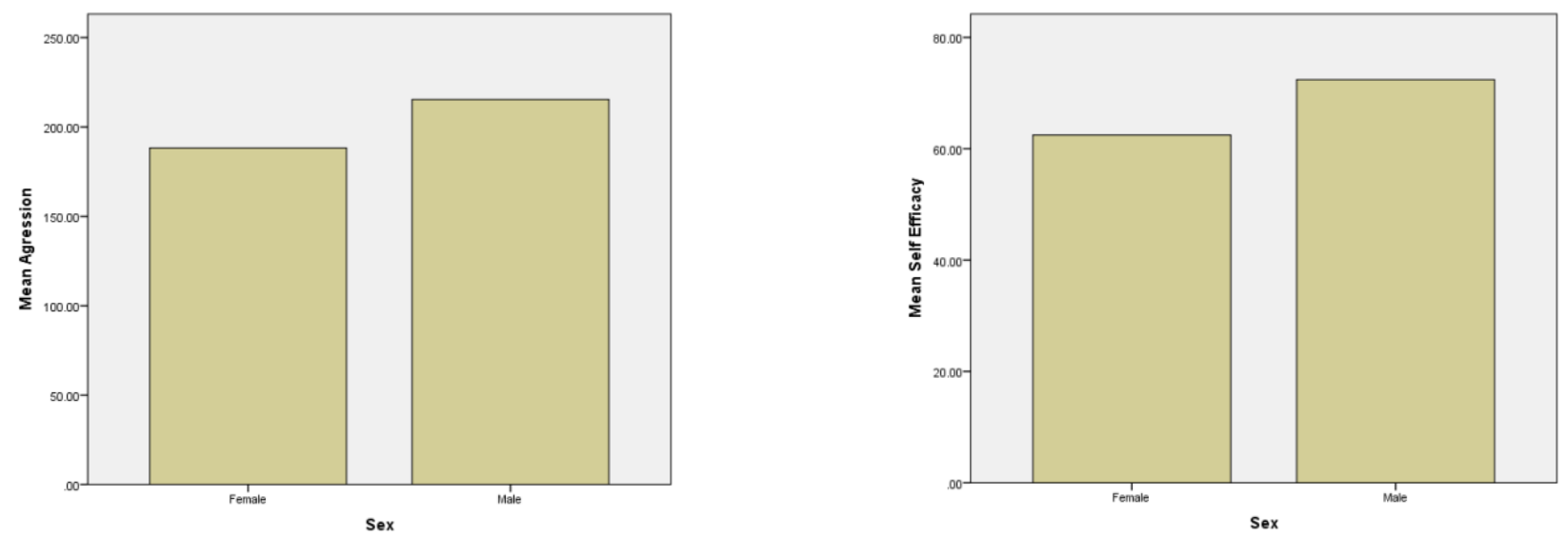

From the table 1 it is clearly seen that male students have scored high on aggression (mean = 215.35, $\mathrm{SD}=12.26$ ), self-efficacy (mean $=72.42, \mathrm{SD}=4.96$ ) also the female students have scored high on aggression $($ Mean $=188.25, \mathrm{SD}=11.05)$, self- efficacy $($ mean $=62.42, \mathrm{SD}=1.88)$ The obtained ' $t$ ' value of aggression (10.38) and self-efficacy (11.88) is significant at 0.01 level.

Table 2

The correlation between aggression and self-efficacy.

Correlations
\begin{tabular}{l|l|c|c}
\hline \multicolumn{1}{l}{ Aggression } & Self-Efficacy \\
\hline \multirow{4}{*}{ Aggression } & Pearson Correlation & 1 & .588 \\
\cline { 2 - 4 } & Significance & & 0.01 \\
\cline { 2 - 4 } Self-Efficacy & $\mathrm{N}$ & 80 & 80 \\
\hline & Pearson Correlation & .588 & 1 \\
\cline { 2 - 4 } & Significance & 0.01 & \\
\cline { 2 - 4 } & $\mathrm{N}$ & 80 & 80
\end{tabular}

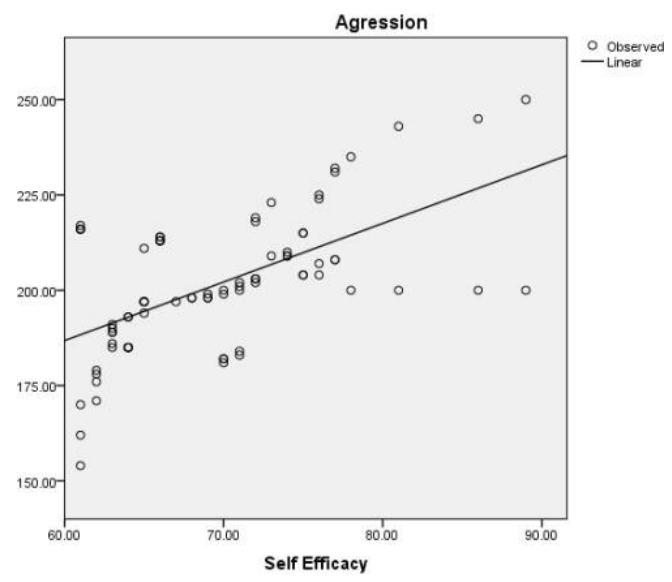


A glance at table 2 indicates that college students' aggression is positively related to self-efficacy $(\mathrm{r}=.588, p<0.01)$. The present study's findings indicate that the higher the self-efficacy, the higher the aggression among college students. Thus, both hypotheses, 'The association between self-efficacy and aggression will be positive and significant,' are accepted.

\section{Conclusions and Discussion}

This study aims to examine the relationship between self-efficacy and aggression in Hindi college students using two instruments measuring the variables. Aggression is measured using a scale developed by Dr. G. P. Mathur and Dr. Raj Kumari Bhatnagar and self-efficacy is measured by a scale by Dr. G. P. Mathur and Raj Kumari Bhatnagar in Hindi and English language. Both scales represent the Hindi samples better as the instrument was built using Hindi sample as well. This study a wide range of theories to analyse the influencing factors of aggression, especially social cognitive theory by Bandura that stated strong self-efficacy may be able to regulate the aggressive behaviour.

Using college students as sample, researcher hopes that the result may be relevant since at this period of developmental stages (at the age of 18-21 years old) people tend to have strong interpersonal relationship in which they may create conflicts which lead to aggression. The result of correlation test shows that self-efficacy and aggression have significant positive correlation. This founding indicates that college students with strong self-efficacy will have greater tendency of aggressive behaviour when conflicts exist in their interpersonal relationship. This result shows that high self-efficacy may be troublesome when it comes to maintaining good and healthy interpersonal relationship with peers.

The level of aggression in female and male college students differ from each other, indicating that male students generally have higher tendency of aggressive behaviour compared to their counterparts. Male college students also have stronger self-efficacy than female college students as males are usually more confidence and perceived as more capable than their counterparts from the cultural perspective.

Based on the result of this study, a recommendation can be given to future research to examine the causes of aggression and self-efficacy discrepancies between female and male college students. There should be better explanation that may involve cultural or demographic analysis regarding the differences across genders.

One of the limitations of this study involves the correlation design in which no causal relationship can be analyzed. Causal relationship may enhance the theory and analysis, therefore future researches should adopt longitudinal design to examine the process of how self-efficacy influences aggression. The second limitation is the lack of analysis on mediating variables, such as self-control, personality, and self-esteem, that may help researcher reveal more results. This study also revealed different result with previous research, therefore further analysis needs to be done to see why this happen and other factors that might give contribution to the relation between these two variables. Suggestions for future research on the same variables include the more concept theories of self-efficacy from various sources, better instrument and validity test, and developmental changes that influence self-efficacy.

The lack of variables in this study suggests future research to examine the learning environment, adolescents' family environment, and peer communication. 


\section{References}

Anderson, C. A., and Bushman, B. J. (2002). Human aggression. Annu. Rev. Psychol. 53, 27-46. doi: 10.1146/annurev.psych.53.100901.135231

Bandura, A. (1973). Aggression: a social learning analysis by albert bandura. Am. J. Sociol. 26, 11011109. doi: $10.2307 / 1227918$

Bandura, A. (1994). "Social cognitive theory and exercise of control over HIV infection," in Preventing AIDS: Theories and Methods of Behavioral Interventions, eds R. J. DiClemente and J. L. Peterson (New York, NY: Plenum), 25-59.

Bandura, A. (1997). Self-efficacy: The Exercise of Self-control. New York, NY: Freeman.

Baron, R. A., Branscombe, N. R., and Byrne, D. (2012). Social Psychology $13^{\text {th }}$ ed. Pearson Publication, New Delhi. Pp 326.

Baumeister, R. F., Vohs, K. D., Tice, D. M. (2007). The strength model of selfcontrol. Current Directions in Psychological Science, 16, 351-355. doi: 10. 1111/j.1467-8721.2007.00534.X

Caprara, G. V., Gerbino, M., Paciello, M., Di Giunta, L., and Pastorelli, C. (2010). Counteracting depression and delinquency in late adolescence: the role of regulatory emotional and interpersonal self-efficacy beliefs. Eur. Psychol. 15, 34-48. doi: 10.1027/1019040/a000004

Buser, T. J., Peterson, C. H., and Kearney, A. (2015). Self-efficacy pathways between relational aggression and non-suicidal self-injury. J. Coll. Counsel. 18, 195-208. doi: 10.1002/jocc.12014

DeWall, C. N., Finkel, E. J., Denson, T. F. (2011). Self-control inhibits aggression. Social and Personality Psychology Compass, 5(7), 458-472. doi: 10.1111/ j.1751-9004.2011.00363.x

Gallagher, J. M., \& Asford, J. B. (2016). Buss- perry aggression questionnaire: Testing alternative measurement models with assaultive misdemeanor offenders. Criminal Justice \& Behavior, 43(11), 1639- 1652. doi: 10.1177/0093854816643986

Ganooverway, L. A., Newton, M., Magyar, T. M., Fry, M. D., Kim, M. S., and Guivernau, M. R. (2009). Influence of caring youth sport contexts on efficacy- related beliefs and social behaviors. Dev. Psychol. 45, 329-340. doi: 10.1037/ a0014067

Hadley, J., Mowbray, T., \& Jacobs, N. (2017). Examining the mediating effect of self-efficacy on approval of aggression and proactive aggression. Journal of school violence, 16(1), 86-103.

Hartono, D. R. (2012). Pengaruh Self-efficacy (efikasi diri) terhadap tingkat kecemasan mahasiswa Fakultas Kedokteran Universitas Sebelas Maret.

Hastuti, L. W. (2018). Kontrol diri dan agresi: Tinjauan meta-analisis. Buletin Psikologi, 26(1), 4253.

Logsdon, M. C., Foltz, M. P., Scheetz, J., \& Myers, J. A. (2010). Self-efficacy and postpartum depression teaching behaviors of hospital-based perinatal nurses. The Journal of perinatal education, 19(4), 10-16.

Mathur, G. P., Bhatnagar, R. K., (2012). Manual for Aggression Scale, Rakhi Prakashan, Agra.

Michele, W. (2008). Exploring the relationship between self-efficacy and aggression in the groupof adolescents in the Peri-urban town of Worcester. http://hdl.handle.net/10019.1/1515

Pajares, F., \& Schunk, D. H. (2001). Self-beliefs and school success: Self-efficacy, self-concept, and school achievement. Perception, 11(2), 239-266. 
Perry, D. G., Perry, L. C., \& Rasmussen, P. (1986). Cognitive social learning mediators of aggression. Child Development, 57(3), 700-711. Retrieved from http://www. jstor.org.ezproxy.lib.monash.edu.au/stable/1130347 doi:10.2307/1130347

Reyna, C., Sanchez, A., Ivacevich, M. G. L., \& Brussino, S. (2011). The Buss-Perry Aggression Questionnaire: construct validity and gender invarianceamong Argentinean adolescents. International Journal of Psychological Research, 4(2), 30-37.

Stangor, C., Jhangiani, R. and Tarry, H. (2014). Principles of Social Psychology, International edition, pp-98. BCcampus Publication. https://opentextbc.ca/socialpsychology/

Tangney, J. P., Baumeister, R. F., \& Boone, A. L. (2004). High self-control predicts good adjuesment, less pathology, better grades, and interpersonal succes. Journal of Personality, 72, 271-322.

Tuncay, O. and Murat, K. (2020). Examining the relationship between self-efficacy and Aggression levels of students interested in weightlifting sports, African Educational Research Journal, Vol. 8(4), pp. 681-688.

U Scholz, G B Dona, S Sud, R Schwarzer. (2002). Is general self-efficacy a universal construct. European Journal of Psychological Assessment, Vol. 18, pp. $242-251$

Wei, P., Chen, H.-B., and Song, B.-P. (2008). Preliminary establishment of sports sense of selfefficacy scale. J. Xian. Phys. Educ. Univ. 25, 128-130. doi: 10.16063/ j.cnki.issn1001$747 x .2008 .04 .030$ 